\title{
STUDIES ON FATTY ACIDS AND STEROLS CONTENT OF SOME CHLOROPHYCEAN MEMBERS.
}

\author{
Mervat F. El-Sherif*; Sami H. Shaalan** and \\ Nagwa. G. Mohammady** \\ * Faculty of Education, Alexandria University, Alexandria, Egypt. \\ ** Faculty of Science, Alexandria University, Alexandria, Egypt.
}

\begin{abstract}
In this work some major marine green algal taxa and the fresh water Chara species were selected and subjected to sterols and fatty acid analyses. Fatty acid analyses indicated that most of the extracted acid fractions were of the polyunsaturated ones (C16, $\mathrm{C} 18$ and $\mathrm{C} 20$ ) with some unusual fractions of $\mathrm{C} 17$ and $\mathrm{C} 19$. Fatty acids as a taxonomic tool gave a particular picture for each investigated taxa that characterized each member. High similarity matrices were observed between Dunaliella salina, Chlorella salina and Enteromorpha compressa. Sterol data indicated that most of the tested algae contained $\Delta^{5}$, $\Delta^{5,22}, \Delta^{7}$ sterols, peptosterol and the saturated nucleus campestanol. Sterol analyses showed clear variations between genera of the different orders: spinasterol was detected only in Ulvales while $5 \beta$ cholestanol and $5 \beta$ cholest-7-en- $\beta$-ol in Chlorococcales and 5, 22, 24 cholestatrien $-3 \beta$-ol was detected only in Charales. In general view, data of sterols and fatty acids indicated that Chara species could be placed among green algae.
\end{abstract}

\section{Introduction}

In respect of morphology, green algae include nearly all thallus forms ranging from unicellular to large thalloid forms. The taxonomy of the green algae has been lastely clarified by applying biochemical and physiological characters (Klessler, 1984). Lipid constituents, most frequently studied in green algae are fatty acids (Erwin, 1973, Attavian, et al., 1977) and sterols (Volkman, et al., 1980 and Mohammady, et al. 2000). Chemotaxonomic survey of sterols and fatty acids in six marine raphidophyte algae was investigated by Marshall, et al. (2002).

Sterols in plants are considered mainly membrane components (Izzo, et al. 1988). Sterols composition of algae has been considered by some authors as potential taxonomic criterion for marine microalgae (Fabregas, et al., 1997), for dinoflagellates (Robinson, et al., 1987), for chrysophytes (Granwell, et al., 1988), for green algae (Belanger, et al., 1973, Granwell, et al., 1990 and Mohammady, et al. 2000), for diatoms (Volkman and Hallegraeff, 1988) and for blue green algae (Kohlhase and Pohl, 1988).

There is much variety in the sterol constituents of Chlorophyta in which a range of $\Delta^{5}-\Delta^{7}$ and $\Delta^{5,7}$ sterols with methyl or ethyl constituents at C24 have been detected as major sterols (Goad, 1978 and Akihisa, et al. 1991). In order Chlorococcales $\Delta^{7}$ and $\Delta^{7,22}$ were the dominant sterols detected in Scenedesmus 
quadricauda, Ankistrodesmus, Oocystis, Selenastrum and Chlorella by Granwell, et al. (1990). Furthermore, species of Dunaliella were characterized by complex distribution of $\Delta^{5}, \Delta^{7}, \Delta^{5,7}$ sterols while Eudorina contains both $\Delta^{5}$ and $\Delta^{7}$ sterols only (Granwell, et al. 1990).

Fatty acids are also important constituents of algae where they are located principally in the cell membrane. They have different valuable functions on algae and have value for taxonomic purposes (Stefanov, et al., 1988). Systematic variations of fatty acids have been studied by many investigators (Nicholas, 1970, Jamieson and Reid, 1972, Abd El-Salam 1997 and Mohammady, et al. 2002). Fatty acids provide more useful information about the classification of Phaeophyta, Rhodophyta and Chlorophyta (Jamieson and Reid, 1972) and in fresh water Chlorophyta (Granwell, et al., 1990). As criteria for chemotaxonomy, Volkman, et al. (1991) suggests that polyunsaturated fatty acids C18:4, C20:5 and C22:6 comprised $83-90 \%$ of the total fatty acids in each of the four species of genus Pavlova. However, distribution of unusual polyunsaturated fatty acid fraction C16:4 in some species of green algae analyzed by Dembitsky, et al. (1991) deserve special attention and investigation. Also, C20 polyunsaturated fatty acids are the characteristic fatty acids in many members of Rhodophyceae,

Phaeophyceae, Chrysophyceae, Haptophyceae, Bacillariophyceae, Xanthophyceae and Chlorophyceae (Wood, 1974 and Arao, et al. 1987).

Fatty acid composition of six arctic and fourteen Antractic macroalgae species belonging to Rhodophyta, Phaeophyta and Chlorophyta were investigated by Graeve, et al. (2002).

The aim of the present work is concentrated on the analysis of sterols and fatty acid composition in some members belonging to chlorophycean orders as a means for their use as taxonomic tools.

\section{Materials and Methods}

\section{The biological materials}

The biological materials (following the classification proposed by Bold and Wynne, 1978) were four species of Ulvales (Ulva lactuca, U. fasciata, Enteromorpha intestinalis and E. compressa), two species of Cladophorales (Cladophora graminea and C. albida), five species of Caulerpales (Caulerpa prolifera, C. racemosa, Codium dichotomum, C. tomentosum and C. elongatum) and two species of Siphonocladales (Cladophoropsis membranacea and Valonia utricales). They were collected from different localities from Ras-Elten to AbuKir along the Mediterranean Sea shore of Alexandria at 2001.

The Volvocales member was the unicellular green alga Dunaliella salina, isolated from brine water of salty lagoons at El-Max district (Alexandria). It was purified and identified using the key of Masjuk (1972). The Chlorococcales member Chlorella salina was obtained from the Institute of Oceanography and 
Fisheries at Alexandria (ARE), while Chara fragilis was collected from Mariut Lake.

For collection of marine algae visits were made to each locality of the Mediterranean Sea shore and healthy specimens were picked out, washed several times by sea water to remove sand particles, epiphytes and then taken to the laboratory in plastic bags immersed in water. The herbarium specimens of late professor Nasr (late Professor of Phycology, Faculty of Science, Alexandria University) were mainly used for identification of the collected taxa.

\section{Lipid extraction and identification of fatty acids}

Total lipid was extracted from algal cells with chloroform methanol (2:1). The chloroform layer containing the total lipid was evaporated to dryness and saponified by boiling for 2 hours in $50 \mathrm{ml}$ of $2 \mathrm{M} \mathrm{NaOH}$ in $50 \%$ ethanol (Dembitsky, et al., 1991). The saponifiable fractions were converted into fatty acid methyl esters (FAME) using the procedure applied by Radwan (1991). FAME were identified on a Shimadzu gas liquid chromatography (GLC), equipped with a flame ionization detector with packing column material Hp-5. The carrier gas was nitrogen and the short speed was $5 \mathrm{~mm} / \mathrm{min}$. Identification of each fatty acid was carried out by comparing its retention times with those of standards. The percentage of concentration was based on the internal standard method.

\section{Isolation, purification and identification of sterols}

The unsaponifiable matter was extracted according to Ramadan and Morsel (2002). The unsaponifiable matter was extracted three times with $10 \mathrm{ml}$ of petroleum ether; the extracts were combined and washed three times with $10 \mathrm{ml}$ of ethanol/water $(1: 1, \mathrm{v} / \mathrm{v})$ mixture, then dried over anhydrous sodium sulphate. The combined extract was evaporated in a rotary evaporator at $25{ }^{\circ} \mathrm{C}$ under reduced pressure; the residual ether was then completely evaporated under nitrogen.

Sterols were isolated according to Nadal (1971) and purified using thin layer chromatography (TLC) plastic sheet of precoated silica gel. The gel layer is $250 \square \mathrm{m}$ thick. The sterols were analyzed by direct injection into GLC-4 cm Schimadzu coated with $30 \%$ SE-30. The carrier gas was nitrogen with the flow rate $30 \mathrm{ml} / \mathrm{min}$. Identification of sterol fractions were carried out by comparing their retention times with those of standard. Quantification was based on the internal standard method.

\section{Estimation of similarity coefficient:}

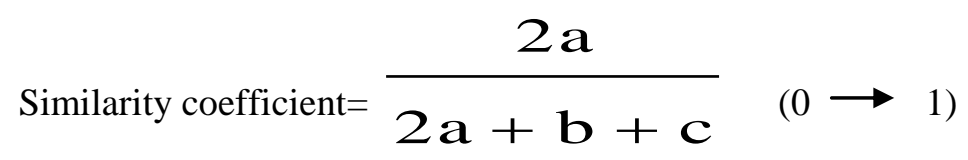

Where a number of similar fatty acid or sterol in both species.

Egyptian J. of Phycol. Vol. 5, $2004 \quad-37$ - 
$\mathrm{b}$ number of marker fatty acid or sterol in first species.

c number of marker fatty acid or sterol in second species.

It assumes values from zero for nil similarity or complete dissimilarity to unity for complete similarity. The coefficient $(0 \longrightarrow 1)$ has been expressed as a percentage $(0 \%-100 \%)$. The coincidences of Czekanowski's coefficient actually represent the extent of similarity between the two operational taxonomic units (OUT's) rather than others (Czekanowski, 1913).

\section{Results and Discussion}

The sterol constituents of the studied green algal taxa that belong to different orders and families have been investigated. Table (1) shows the 17 sterol fractions and their concentrations as a percentage of total sterols that were found among the investigated taxa. The results obtained show that beside the saturated nucleus fraction campestanol $\left(\Delta^{0}\right)$, most of the investigated algal members contained also the common $\Delta^{5}$ unsaturated sterols: Cholesterol, $\beta$ - sitosterol and Isofucosterol. These compounds are characterized by the presence of methyl or ethyl substituents at C-24. The most sterols commonly distributed in higher plants have a methyl or ethyl group at C-24 on the side chain (Uomori, 1992) which runs in parallel with our results for green algae. Some other algal members might contain $\Delta^{5,22}$ i.e. stigmasterol while still others have a variety of sterol constituents of $\Delta^{7}$ as avenasterol and isoavenasterol. These results go in harmony with those obtained by Akihisa, et al. (1991) who reported that both $\Delta^{5}$ and $\Delta^{7}$ sterols represent the main constituents among green algae.

However, 5,22,24- cholesta-trien - $3 \beta$-ol was detected only in Chara fragilis but Chlorella salina was the only investigated alga that contained both $5 \beta$ - cholestanol and $\alpha 5 \beta$ cholest - 7- en $\beta$ - ol. While $14 \alpha$ - methyl $5 \alpha$ - cholest (14) en - $3 \beta$ - ol was detected in Enteromorpha intestinalis, but $5 \alpha$ stigmast - 7en $-3 \beta$ - ol was detected only in both Ulva fasciata and Codium tomentosum. This fraction was previously detected in some algae by Thompson, et al. (1980) and in Acacia sp. by Abd El- Salam (1997). Cycloartenol was detected only in both Valonia utricales and Cladophoropsis membranacea. Ulva lactuca was the only species among green algae that contained spinasterol, an isomer of stigmasterol found in Spinache, Alfalfa and Senega root (Harborne, 1973). The remaining sterol individuals were distributed among all the investigated members as shown in table (1). 
Studies on Fatty Acids and Sterols Content of Some Chlorophycean Members.

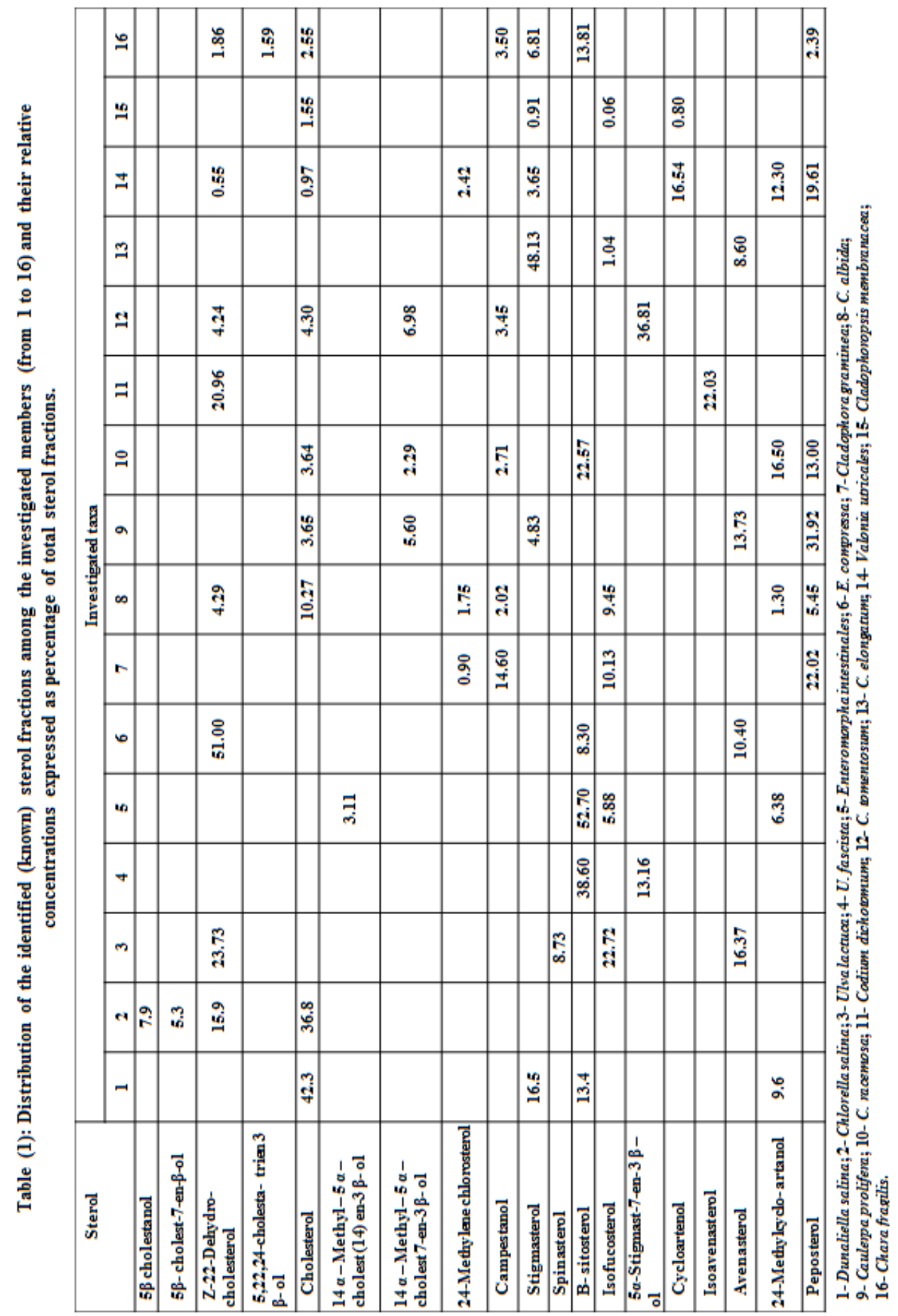


From a comparative point of view $\beta$ - sitosterol, was the predominant fraction in both Ulva fasciata and Enteromorpha intestinalis. It constituted nearly $38.6 \%$ and $52.7 \%$ of the total sterol fractions respectively. Members of order Caulerpales i.e. Caulerpa prolifera, Caulerpa racemosa and Codium tomentosum contained $14 \alpha$ methyl $-5 \alpha$ cholest -7 en $-3 \beta$ - ol.

The results of sterol analyses of Dunaliella salina indicated the presence of four unsaturated sterol fractions: cholesterol $42.3 \%$, stigmasterol $16.5 \%, \beta$ sitosterol $13.4 \%$ and 24 methyl cycloartanol $9.6 \%$ of the total sterols. All these sterols are of the advanced type except 24 methylcycloartanol which is a primitive one. These results for Dunaliella salina coincides with those obtained by Mohammady (2002).

The similarity matrices and dendrogram of the studied algal taxa based on the distribution of their sterol fractions were recorded in Table (2) and Figure (1). It is obvious from this table and figure, that highly significant similarity was found between Cladophora graminea and C. albida (72.7 \%), followed by Cladophora albida and Valonia utricales $(71.4 \%)$. The similarity matrices between Cladophora albida and Caulerpa racemosa was $66.7 \%$ while between Chara fragilis and Caulerpa racemosa it was $61.51 \%$. At the same time the similarity matrices between both Caulerpa racemosa and Dunaliella salina was $60 \%$; while, this correlation reached about $57.1 \%$ between each pair of the following taxa: Cladophoropsis membranacea and Codium elongatum, Chara fragilis and Valonia utricales, Enteromorpha compressa and Ulva lactuca and finally between Codium elongatum and Ulva lactuca. Lastly, the similarity matrices between Caulerpa racemosa and Caulerpa prolifera, Codium tomentosum and Caulerpa racemosa and between Valonia utricales and Dunaliella salina were $54.5 \%$. It is clear from the above mentioned results that similarity matrices between Chara fragilis and some representative genera in descending order could be arranged as follows: $61.5 \%$ for Caulerpa racemosa followed by $57.1 \%$ for Valonia utricales, $54.5 \%$ for Dunaliella salina and $50 \%$ for both Caulerpa prolifera and Codium tomentosum. These results encourage the authors to place Chara species at the top rank among members of Chlorophyta.

Anent, GLC data was concerning the fatty acids distribution (Table 3). The results obtained indicated variations in carbon chain lengths that ranged between C8 and C24 with differences in the degree of saturation. Fourteen saturated fatty acids and twenty-one unsaturated ones were detected. The distribution of fatty acid fractions and their relative concentrations differed according to the types of algal taxa.

C18:2 demonstrated the mostly wide distributed fraction between the operational taxonomic units (OUT's), while C12:0 shows a minimum representation among fatty acid fractions. The last one was detected only in Dunaliella salina. Codium elongatum was the only investigated alga that contained C21:0, while Ulva fasciata contained only C17:4. The remaining detected fatty acid fractions were unevenly distributed among all 
Table (2): The similarity matrices of the investigated members (from 1 to 16) in relation to their sterols composition.

\begin{tabular}{|c|c|c|c|c|c|c|c|c|c|c|c|c|c|c|c|c|}
\hline $\begin{array}{c}\text { Operational } \\
\text { taxonomic } \\
\text { unit }\end{array}$ & 1 & 2 & 3 & 4 & 5 & 6 & 7 & 8 & 9 & 10 & 11 & 12 & 13 & 14 & 15 & 16 \\
\hline 1 & - & 25.0 & 0.0 & 333 & $\mathbf{5} 0.0$ & 28.6 & 0.0 & 36.4 & 44.4 & 60.0 & 0.0 & 22.2 & 28.6 & 54.5 & 50.0 & 54.5 \\
\hline 2 & & - & 25.0 & 0.0 & 0.0 & 28.6 & 0.0 & 36.4 & 22.2 & 20.0 & 33.3 & 44.4 & 0.0 & 36.4 & 25.0 & 36.4 \\
\hline 3 & & & - & 0.0 & 25.0 & 57.1 & 25.0 & 36.4 & 22.2 & 0.0 & 33.3 & 22.2 & 57.1 & 18.2 & 25.0 & 18.2 \\
\hline 4 & & & & - & 33.3 & 40.0 & 0.0 & 0.0 & 0.0 & 25.0 & 0.0 & 28.6 & 0.0 & 0.0 & 0.0 & 22.2 \\
\hline 5 & & & & & - & 28.6 & 25.0 & 36.4 & 0.0 & 40.0 & 0.0 & 0.0 & 28.6 & 18.2 & 25.0 & 18.2 \\
\hline 6 & & & & & & - & 0.0 & 20.0 & 25.0 & 22.2 & 40.0 & 25.0 & 33.3 & 20.0 & 0.0 & 40.0 \\
\hline 7 & & & & & & & - & 72.7 & 22.2 & 40.0 & 0.0 & 22.2 & 28.6 & 36.4 & 25.0 & 36.4 \\
\hline 8 & & & & & & & & - & 33.3 & 66.7 & 22.2 & 50.0 & 20.0 & 71.4 & 36.4 & 42.9 \\
\hline 9 & & & & & & & & & - & 54.5 & 0.0 & 40.0 & $\mathbf{5} 0.0$ & $\mathbf{5 0 . 0}$ & 44.4 & 50.0 \\
\hline 10 & & & & & & & & & & & 0.0 & 54.5 & 0.0 & 46.1 & 20.0 & 61.5 \\
\hline 11 & & & & & & & & & & & & 28.6 & 0.0 & 33.3 & 0.0 & 22.2 \\
\hline 12 & & & & & & & & & & & & & 0.0 & 33.3 & 22.2 & $\mathbf{5} 0.0$ \\
\hline 13 & & & & & & & & & & & & & - & 20.0 & 57.1 & 20.0 \\
\hline 14 & & & & & & & & & & & & & & - & 54.5 & 57.1 \\
\hline 15 & & & & & & & & & & & & & & & - & 36.4 \\
\hline 16 & & & & & & & & & & & & & & & & - \\
\hline
\end{tabular}

1- Dunaliella salina; 2- Chlorella salina; 3- Ulva lactuca; 4- U. fascista;

5- Enteromorpha intestinales; 6- E. compressa; 7- Cladophora graminea; 8- C. albida; 9- Caulerpa prolifera; 10- C. racemosa; 11- Codium dichotomum; 12- C. tomentosum; 13- C. elongatum; 14- Valonia utricales; 15-Cladophoropsis membranacea; 16- Chara fragilis. 


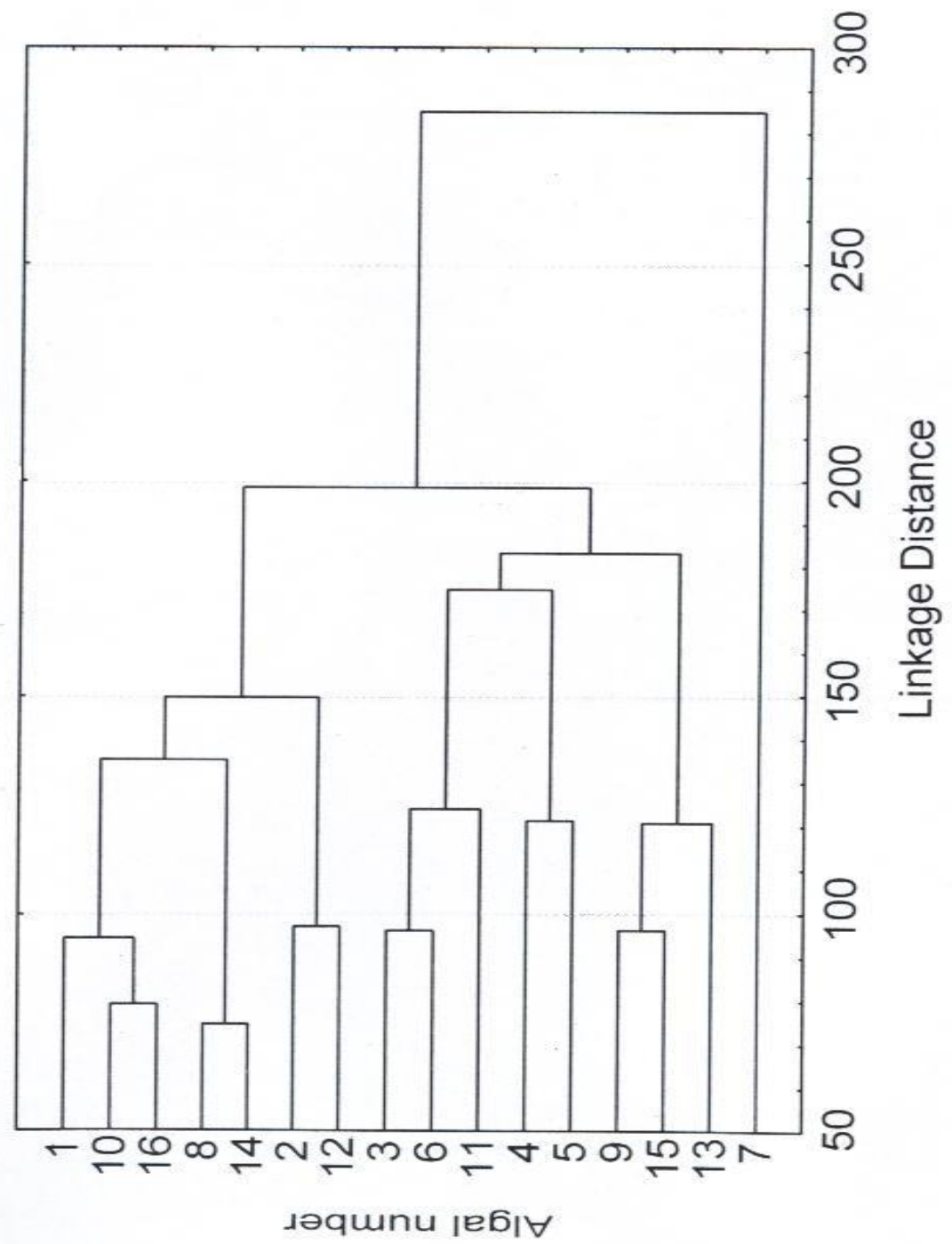

Figure (1): The dendrogram of the investigated members (from 1 to 16) in relation to their sterols composition.

1- Dunaliella salina; 2-Chlorella salina; 3-Ulva lactuca; 4- U. fascista;

5- Enteromorpha intestinales; 6- E. compressa; 7- Cladophora graminea; 8- C. albida;

9- Caulerpa prolifera; 10- C. racemosa; 11- Codium dichotomum; 12- C. tomentosum;

13- C. elongatum; 14- Valonia utricales; 15-Cladophoropsis membranacea; 16- Chara fragilis. 


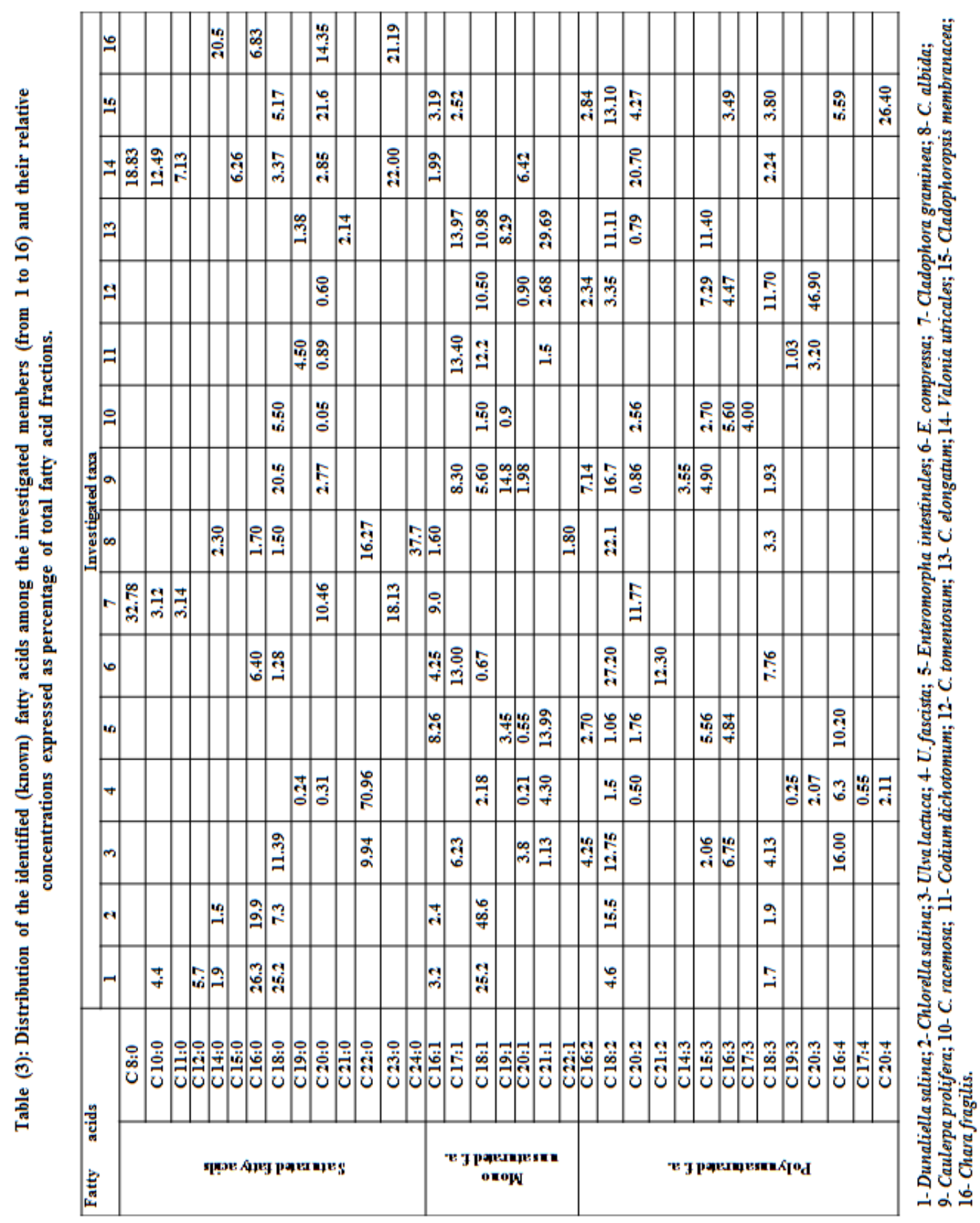


the investigated taxa. Different Dunaliella species were previously analyzed by some authors for their fatty acid composition and was found to be identical to most green algae. Fried et al. (1982) found that Dunaliella bardawil contained C16:0, C16:1, C16:4, C18:0, C18:2 and C18:3 acids, a distribution pattern which in parallel with the results obtained for Dunaliella salina except that C16:4 fraction was not detected. The same author found that C16:1 which occurs in the phosphatidyl glycerol of most micro-algae is thought to be important in plant photosynthesis. Graeve et al. (2002) reported that Chlorophyta comprise the most modern group and this is supported by primarily C18 unsaturated fatty acid typical of the vegetative tissue of higher plants. This agrees with the results obtained that $\mathrm{C} 18: 1, \mathrm{C} 18: 2$ and $\mathrm{C} 18: 3$ demonstrated the mostly wide distributed fractions between the investigated green algae. C18:2 were detected in Enteromprpha compressa, Caulerpa prolifera, Chlorella salina, Ulva lactuca and C18:1 in Chlorella salina, Dunaliella salina, Codium dichotomum, Codium tomentosum and in Codium elongatum. However, C18:0 and C18:3 were detected in nine species of the green algal members but at lower concentrations. Cladophora albida is the only investigated alga that contained the long chain saturated fatty acid C24. However, the results obtained for C. albida appear to be similar to those obtained by Jamieson and Reid (1972) for C. albida. All investigated Codium species contained C18:1 and this is consistent with results obtained by Aknin et al. (1992).

The fatty acid fractions obtained in Cladophoropsis membranacea (siphonales) indicated the frequent distribution of C16 fractions (nearly $1 / 2$ of the total fractions). This coincides with the results obtained by Aknin et al. (1992) who proved the frequently detected $\mathrm{C} 16$ within siphonales taxa. However an appreciable amount of C20 was detected which nearly reached $21.6 \%$ of the total fatty acids. Our results indicated that most fatty acids of the investigated algal taxa are of the polyunsaturated ones. The highly dominant fractions are C16, C18 and C20 while C17 and C19 fractions are the least. Finally, the results indicated also that four ulvacean members can be distinguished by $\mathrm{C} 18: 2$ fatty acids, the cladophoracean members by $\mathrm{C} 16: 1$ fatty acid and the siphonous members and characean members by $\mathrm{C} 20: 0$ fatty acids.

The similarity matrices and dendrogram of the studied algal materials based on their fatty acids distribution were represented in table (4) and figure (2). These data reflected considerable relation between the investigated algal members. The highest similarity value $(87.8 \%)$ existed between Dunaliella salina and Chlorella salina followed by Chlorella salina and Enteromorpha compressa $(80 \%)$ followed by Cladophora greaminea and Valonia utricales (77.8 \%). The similarity value between Caulerpa prolifera and Caulerpa racemosa as well as between Enteromorpha intestinalis and Codium tomentosum as well as between Ulva fasciata and Codium dichotomum reached $60 \%$. It is obvious therefore that low similarity value was observed between the two members of Ulvales and between the two investigated members of Caulerpaceae. 
Table (4): The similarity matrices of the investigated members (from 1 to 16) in relation to their fatty acids composition

\begin{tabular}{|c|c|c|c|c|c|c|c|c|c|c|c|c|c|c|c|c|}
\hline $\begin{array}{l}\text { Operational } \\
\text { taxonomic } \\
\text { unit }\end{array}$ & 1 & 2 & 3 & 4 & 5 & 6 & 7 & 8 & 9 & 10 & 11 & 12 & 13 & 14 & 15 & 16 \\
\hline 1 & - & 87.5 & 30.0 & 18.2 & 21.1 & 70.6 & 25.0 & 66.7 & 38.1 & 23.5 & 12.5 & 31.6 & 18.2 & 40.0 & 40.0 & 30.8 \\
\hline 2 & & - & 33.3 & 20.0 & 23.5 & 80.0 & 14.3 & 75.0 & 42.1 & 26.7 & 14.3 & 35.3 & 25.0 & 33.3 & 44.4 & 36.4 \\
\hline 3 & & & - & 33.3 & 66.7 & 42.1 & 0.0 & 40.0 & 60.9 & 31.6 & 22.2 & 66.7 & 40.0 & 27.3 & 63.6 & 0.0 \\
\hline 4 & & & & - & 43.5 & 19.0 & 20.0 & 9.1 & 40.0 & 28.6 & 60.0 & 52.2 & 45.5 & 25.0 & 41.7 & 11.8 \\
\hline 5 & & & & & - & 22.2 & 23.5 & 21.1 & 54.5 & 44.4 & 11.8 & 60.0 & 52.6 & 28.6 & 57.1 & 0.0 \\
\hline 6 & & & & & & - & 13.3 & $\mathbf{5 8 . 8}$ & $\mathbf{5 0 . 0}$ & 25.0 & 26.7 & 33.3 & 35.3 & 31.6 & 52.6 & 16.7 \\
\hline 7 & & & & & & & - & 12.5 & 21.1 & 26.7 & 14.3 & 11.8 & 12.5 & 77.8 & 33.3 & 36.4 \\
\hline 8 & & & & & & & & - & 28.6 & 11.8 & 0.0 & 21.1 & 11.1 & 30.0 & 40.0 & 30.8 \\
\hline 9 & & & & & & & & & - & 60.0 & 31.6 & 63.6 & 57.1 & 52.2 & 60.9 & 25.0 \\
\hline 10 & & & & & & & & & & - & 26.7 & 44.4 & 47.1 & 31.6 & 42.1 & 16.7 \\
\hline 11 & & & & & & & & & & & - & 47.1 & $\mathbf{5 0 . 0}$ & 11.1 & 22.2 & 18.2 \\
\hline 12 & & & & & & & & & & & & - & 42.1 & 28.6 & 47.6 & 14.3 \\
\hline 13 & & & & & & & & & & & & & - & 30.0 & 30.0 & 0.0 \\
\hline 14 & & & & & & & & & & & & & & - & 45.5 & 26.7 \\
\hline 15 & & & & & & & & & & & & & & & - & 13.3 \\
\hline 16 & & & & & & & & & & & & & & & & -- \\
\hline
\end{tabular}

1- Dunaliella salina; 2- Chlorella salina; 3-Ulva lactuca; 4- U. fascista;

5- Enteromorpha intestinales; 6- E. compressa; 7- Cladophora graminea; 8- C. albida;

9- Caulerpa prolifera; 10- C. racemosa; 11- Codium dichotomum; 12- C. tomentosum;

13- C. elongatum; 14- Valonia utricales; 15-Cladophoropsis membranacea;

16- Chara fragilis. 


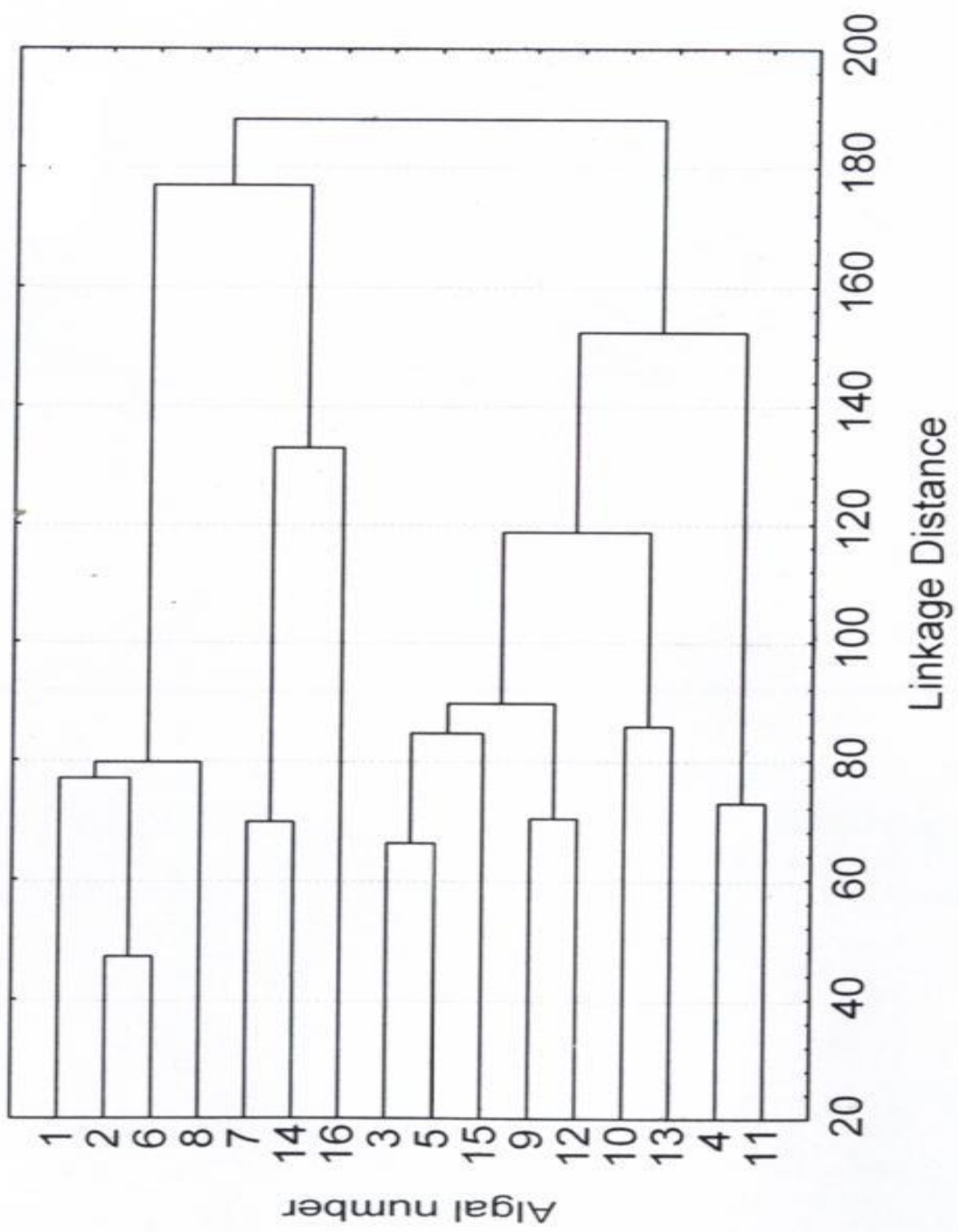

Figure (2): The dendrogram of the investigated members (from 1 to 16) in relation to their fatty acids composition.

1- Dunaliella salina; 2- Chlorella salina; 3- Ulva lactuca; 4- U. fascista;

5- Enteromorpha intestinales; 6- E. compressa; 7-Cladophora graminea; 8- C. albida; 9- Caulerpa prolifera; 10- C. racemosa; 11- Codium dichotomum; 12- C. tomentosum; 13-C. elongatum; 14- Valonia utricales; 15-Cladophoropsis membranacea; 16- Chara fragilis. 
Also a similarity value was observed between the studied members of Ulvales and Caulerpales. A high similarity value was observed between Dunaliella salina, Chlorella salina and the two investigated Enteromorpha species.

The lowest similarity values $(9.1 \%)$ was recorded between Ulva fasciata and Cladophora albida followed by (11.1\%) between Cladophora albida and Codium elongatum as well as between Codium dichotomum and Valonia utricales. A degree of similarity between Cladophoropsis membranacea and Ulva lactuca reached up to $63.6 \%$ while this similarity between Cladophoropsis membranacea and E. intestinalis reached to $57.1 \%$. This may indicate a similarity between $C$. membranacea and ulvacean members. All fatty acids detected in chladophoracean individuals were also observed in Valonia utricales. This result was supported by the obviously high similarity matrices between them (77.8\%).

In conclusion, the results obtained in this work concerning the distribution pattern of fatty acids and sterols in the experimental algal orders could be useful in solving some taxonomic problems among the investigated species and other related taxa.

\section{References}

Abd-El-Salam, E.M. (1997). Comparative taxonomic studies on Charophytes in relation to other green plants. Ph. D. Thesis, Fac.of Sci. Alex. Univ. Alexandria, Egypt.

Akihisa, T; Kojima, S.; Yokota, T. and Tamura, T. (1991). 24- Methylene-25methylcholesterol and both C-24 epimers of 24-ethyl-22Dehydrocholesterol in freshwater green alga Hydrodictyon reticulatum. Phytochemistry, 30: 3621-3624.

Aknin, M.; Nzaon, R.M.; Ciss, E.; Kornprobst, J.M.; Caydon, E.M.; Samb, A. and Miralles, J. (1992). Fatty acids composition of twelve species of Chlorophyceae from the senegales coast. Phytochemistry, 31: 2739-2741.

Arao, T.; Kawaguchi, A. and Yamada, M. (1987). Positional distribution of fatty acids in lipids of the marine diatom Phaeodactylum triconutum. Phytochemistry, 26: 2573-2576.

Attavian, B.N.; Floyd, G.L. and Fairbrothers, D.E. (1977). Fatty acids of filamentous green algae. Biochem. Syst. Ecol., 5: 65-69.

Belanger, P.; Zintel, J. A.; Vander, W. J. and Smith, J. L. (1973). Identification by combined gas liquid chromatography- mass spectroscopy of sterols isolated from Scenedesmus obliquus grown in light and heavy water. Can. J. Chem., 51: 3294-3298.

Bold, H. C. and Wynne, M. J. (1978). Introduction to the Algae. Structure and Reproduction. Prentice Hall Inc., Englewood Cliffs, N.J. 
Czekanowski, J. (1913). Zarys metod statystycznck, E. Wendego, Warsow. Anthropol. Anz., 9: 227- 249.

Dembitsky, V.M.; Elena, E.; Shubina, P. and Rozentsvet, O. A. (1991). Glycolipids and fatty acids of some seaweeds and marine grasses from the Black Sea. Phytochemistry, 30: 2279-2283.

Erwin, J. A. (1973). In lipids Biomembranes of Eukaryotic microorganisms (Erwin, J.A., ed.), pp. 41-143. Academic press. New York.

Fabregas, J.; Aran, J.; Morales, E.D.; Lamela, T. and Otero, A. (1997). Modification of sterol concentration in marine microalgae. Phytochemistry, 46: 1189-1191.

Fried, A.; Tietz, A.; Ben-Amotz, A. and Einchenberger, W. (1982). Lipid composition of the halotolerant alga Dunaliella bardawil. Biochemica et Biophysica. Acta., 713: 419-420.

Goad, L.J. (1978). In marine natural products: chemical and biological prespectives. Vo 2 (Schever, P.J., ed.), p. 75. Academic press. New York.

Graeve, M.; Kattner, G.; Wiencke, C. and Karsten, U. (2002). Fatty acid composition of Arctic and Antractic macroalgae: indicator of phlogeenetic and tropihic relatioships. Mar. Ecol. Prog. Ser., 231:67-74.

Granwell, P.A., Creighton, M. E. and Jaworski, G.H.M. (1988). Lipids of four species of freshwater chrysophytes. Phytochemistry, 27: 1053-1059.

Granwell, P.A., Jawarski, G.H.M. and Bickley, H.M. (1990). Hydrocarbons, sterols, esters and fatty acids in six freshwater chlorophytes. Phytochemistry, 29: 145-151.

Harborne, J.B. (1973). Phytochemical methods. P. 276. Chapman and Hall, London.

Izzo, F.N.; Izoo, R.; Bottazzi, F. and Ranieri, A. (1988). Effects of water stress and salinity on sterols in Zea mays shoots. Phytochemistry, 27: 3109-3115.

Jamieson, G.R. and Reid, E.H. (1972). The component fatty acids of some marine algal lipids. Phytochemistry, 11: 1423-1432.

Kessler, E. (1984). In systematic of the green algae (Irvine, D.E.G. and John, D.M., eds), pp. 391-407. Academic press, London.

Kohlhase, M. and Pohl, P. (1988). Saturated and unsaturated sterols of nitrogenfixing blue- green algae (Cyanobacteria). Phytochemistry, 27: 1735-1740.

Marshall, J. A.; Nichols, P.D.; Hallegraeff, G.M. (2002). Chemotaxonomic survey of sterols and fatty acids in six marine raphidophyte algae. Journal of Applied Phycology, 14(4): 255-265.

Masjuk, N.P. (1972). On phylogeny and taxonomy of the genus Dunaliella salina Teod. Ukranskya Botanichnya Zhornal., 29: 744.

Mohammady, N.G.; Khaleafa, A.F.; Shaalan, S.H. and Abd El-salam, E.M. (2000). Sterols and fatty acids composition of charophytes in relation to some other green plants. Egypt J. Phycol., 1: 169-180. 
Mohammady, N.G.; Khaleafa, A.F.; Shaalan, S.H. and Taha, H.M. (2002). Comparative biochemical taxonomy of some Dunaliella species. Egypt J. Biotechnol., 11: 248-265.

Nadal, N.G.M. (1971). Sterols of Spirulina maxima. Phytochemistry, 10: 25372538.

Nicholas, B.W. (1970). Comparative lipd biochemistry of photosynthetic organisms. In phytochemical phylogeny, ed. Harborne, J.B. pp. 105-18. Academic press, New York and London.

Radwan, S. S. (1991). Sources of C20-polyunsaturated fatty acids for biotechnological use. Appl. Microbiol. Biotechnol., 35: 421-430.

Ramadan, M.F. and Morsel, J.T. (2002). Proximate neutral lipid composition of Niger (Guizotia abyssinica Cass.) Seed. Czech J. Food Sci., 20 (3): 98-104.

Robinson, N.; Granwell, P.A.; Eglinton, G. and Jaworski, G.H.M. (1987). Lipids of four species of freshwater dinoflagellates. Phytochemistry, 26: 411-421.

Stefanov, K.; Knaklieva, M.; Brechany, E. Y. and Christie, W.W. (1988). Fatty acid composition of some algae from the Black sea. Phytochemistry, 27: 3495- 3497.

Thompson, M.J.; Patterson, G.W.; Dutky, S.R., Svoboda, J.A. and Kaplains, J.N. (1980). Techniques for the isolation and identification of steroids in insects and algae. Lipids, 15: 719- 733.

Uomori, A. ; Nakagawa, Y.; Yoshimatsu, S.; Seo, S.; Sankawa, U. and Takeda, K. (1992). Biosynthesis of campsterol and dihydrobrassicasterol in cultured cells of Amonsia elliptica. Phytochemistry, 31: 1569-1572.

Volkman, J.K.; Eglinton, G and Corner, E.D.S. (1980). Sterol and fatty acids of the marine diatom Biddulphia sinensis. Phytochemistry, 19: 1809-1813.

Volkman, J.K. and Hallegraeff, G.M. (1988). Lipids in marine diatoms of the genus Thalassiosira: predominance of 24-methylenecholesterol. Phytochemistry, 27: 1389-1394.

Volkman, J.K.; Dunstan, G.A.; Jeffrey, S.W. and Kearney, P.S. (1991). Fatty acids from microalgae of the genus Pavlova. Phytochemistry, 30: 18551859.

Wood, B.J.B. (1974). In: Algal physiology and biochemistry (Stewart, W.D.P., ed) 236-265 . Blackwell Scientific Publications, Oxford. 


\section{دراسات على محتوى الأحماض الاهنية والأستيرولات لبعض أفراد الطحالب

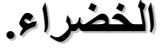

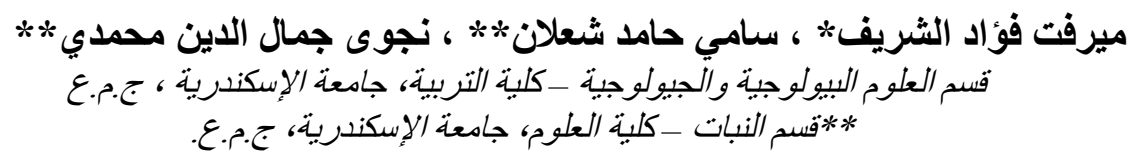

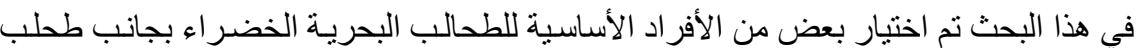

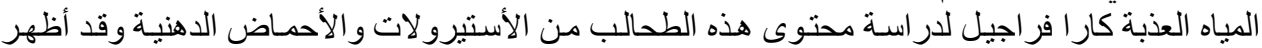

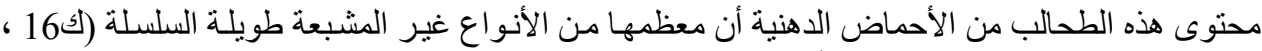

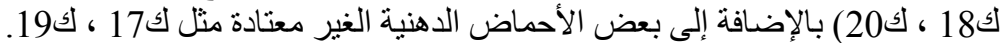

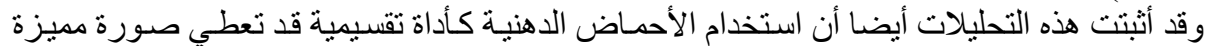

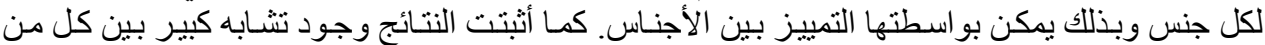

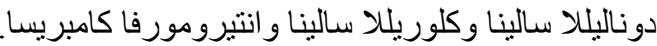

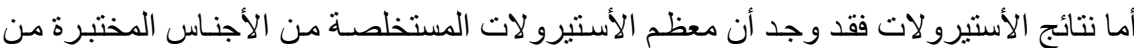

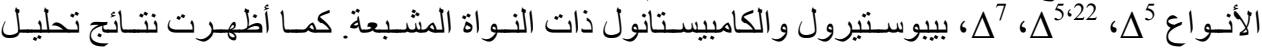

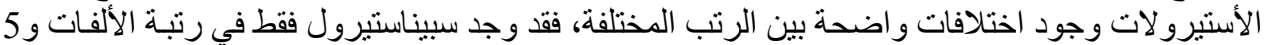

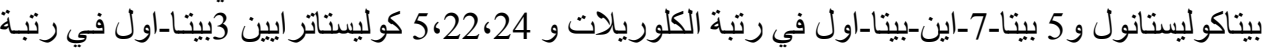

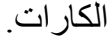

و على وجه العموم أظهرت نتائج تحليل كل من الأستيرو لات و الأحماض الدهنية أنه يمكن وضع الطحالب الكارية ضمن الطحالب الخضر اءؤ نتائ. 